\title{
Field Tests of Predaceous Pentatomid Pheromones and Semiochemistry of Podisus and Supputius species (Heteroptera: Pentatomidae: Asopinae)
}

\author{
Jeffrey R. Aldrich ${ }^{1}$, José C. Zanuncio ${ }^{2}$, Evaldo F. Vilela ${ }^{2}$, Jorge B. Torres ${ }^{2}$ \\ and Ronald D. Cave'. \\ ${ }^{1}$ USDA/ARS, Insect Chemical Ecology Laboratory, B-007, BARC-West, \\ Beltsville, MD, USA 20705. \\ ${ }^{2}$ Departamento de Biologia Animal da Universidade Federal de Viçosa, \\ 36570-00, Viçosa, MG. \\ ${ }^{3}$ Departamento de Proteccion Vegetal, Escuela Agricola Panamericana, \\ El Zamorano, Honduras.
}

An. Soc. Entomol. Brasil (26)1: 1-14 (1997)

Testes de Campo com Feromônios de Pentatomídeos Predadores e Análise Semioquímica de Espécies dos Gêneros Podisus e Supputius (Heteroptera: Pentatomidae: Asopinae)

RESUMO - Armadilhas contendo feromônios sintéticos de Podisus nigrispinus (Dallas) e Supputius cincticeps (Stäl) foram testadas no campo, na Universidade Federal de Viçosa, Minas Gerais, Brasil, a partir de 7 de setembro de 1995. Durante a coleta (setembro-outubro/95), não se observou a presença de $P$. nigrispinus nas armadilhas em teste. No entanto, diversos adultos (machos e fêmeas) de Podisus distinctus (Stäl) foram coletados durante o mesmo período, bem como, alguns adultos de $S$. cincticeps e dois parasitóides fêmeas de Cylindromyia atra Roeder (Diptera: Tachinidae). Análises químicas do extrato glandular de machos de $P$. distinctus indicaram que os principais compostos feromonais desta espécie, também são produzidos por $P$. nigrispinus e $S$. cincticeps. Devido a este fato, em 6 de novembro, foram colocadas no campo uma série de armadilhas contendo iscas feromonais tanto de $P$ nigrispinus, como de $S$. cincticeps. As armadilhas foram monitoradas até 6 de fevereiro de 1996. Durante esta segunda etapa do estudo, observou-se que a combinação das duas iscas feromonais aumentou em seis vezes a coleta de adultos de $P$. distinctus, em comparação com aquelas onde havia somente a isca para $P$. nigrispinus. Embora a fenologia para estes asopines neotropicais seja semelhante à do predador norte-americano de clima temperado Podisus maculiventris (Say), menos predadores e parasitóides hospedeiros foram coletados. Possíveis feromônios foram identificados para Podisus rostralis (Stäl), em Goiás, Brasil, e Podisus sagitta (Fabricius), de Honduras. Compostos químicos de outras secreções exócrinas destas espécies neotropicais também foram estudados.

PALAVRAS-CHAVE: Insecta, Hemiptera, Tachinidae, controle biológico, atração, cairomônio. 


\begin{abstract}
Traps baited with synthetic pheromones for either Podisus nigrispinus (Dallas) or Supputius cincticeps (Stäl) were field tested at the Universidade Federal de Viçosa, Minas Gerais, Brazil, beginning September 7, 1995. No P. nigrispinus were caught but, in September and October, several adult males and females of $P$. distinctus (Stäl) were caught along with a few adults of $S$. cincticeps and two females of a tachinid fly parasitoid, Cylindromyia atra Roeder. Chemical analysis of the pheromone gland extract of $P$. distinctus males indicated that this species produces a pheromone containing the major compounds of P. nigrispinus and S. cincticeps. Therefore, on November 6 a set of traps was baited with the pheromones of both $P$. nigrispinus and S. cincticeps, and monitored in the field until February 6, 1996. During this second phase of the study, six times more $P$. distinctus were caught in the combined pheromone treatment than in traps baited only with the P. nigrispinus pheromone. The phenology of these neotropical asopines is like that for P. maculiventris (Say) in temperate North América, although fewer predators and host-seeking parasitoids were caught. Suspected pheromones were also identified for P. rostralis (Stäl) from Goiás, Brazil, and P. sagitta (Fabricius) from Honduras. In addition, the chemistry of other exocrine secretions from these neotropical species was investigated.
\end{abstract}

KEY WORDS: Insecta, Hemiptera, Tachinidae, biological control, attractant, kairomone.

Species in the genus Podisus (Heteroptera: Pentatomidae) are common generalist predators in the Americas (Thomas 1992), and several are key predators in agricultural ecosystems of the western hemisphere (e.g., Turnipseed \& Kogan 1983, Berti $\mathrm{F}^{\circ}$ \& Fraga 1987). Research on these predators has fundamentally advanced entomological science in two areas: semiochemistry and biological control.

The most common North American species, Podisus maculiventris (Say) (called the "spined soldier bug"), was the first predaceous insect for which a long-range attractant pheromone was identified (Aldrich et al. 1984). The pheromone is also used by a complex of parasitoids as a host-finding kairomone (Aldrich 1995), and behavioral investigations of the spined soldier bug are unveiling surprising interactions between pheromonal and acoustical communication (Pfannenstiel et al. 1995, R. E. Hunt personal communication). In addition to attracting both sexes of adults, adult, the immature spined soldier bugs can be induced to walk toward synthetic pheromone lures placed in upwind rows of field crops (J. Sant'Ana personal communication). Recent evidence indicates that treating artificial diets for Podisus spp. with synthetic pheromone significantily stimulates the young predators to find this unnatural food (J. R. Aldrich unpublished data, J. B. Torres personal communication). An inexpensive, effective synthetic pheromone for $P$. maculiventris has been commercially available since 1992 (Anonymous 1992).

Biological control research using the spined soldier bug as a model predator suggests that classical predation theory has greatly underestimated the importance of predators at low prey density ( 0 'Neil \& Wiedemann 1987,0'Neil 1990, Wiedemann \& 0'Neil 1992). There is an emerging awareness that the most efficacious point to attack pest cycles is at low population densities before pest populations explode. For example, predator augmen- 
tation in early season potato (Solanum tuberosum) can significantly suppress and delay the outbreaks of the Colorado potato beetle (Biever \& Chauvin 1992a,b, Hough-Goldstein \& Keil 1991, Hough-Goldstein \& Whalen 1993). P. maculiventris appears to be particularly well adapted to surviving periods of scarce prey (Legaspi \& O’Neil 1993, 1994, Valicente \& O'Neil 1995).

In North America, commercial insectaries have started selling $P$. maculiventris in limited quantities (Hunter 1994), and a practical artificial diet for these predators is nearing commercial production (P. Greany personal communication). In Brazil P. nigrispinus (Dallas) [= P. connexivus (Bergroth); Thomas 1992] is already being augmented in commercial $E u$ calyptus plantations for biological control of lepidopteran pests (Zanuncio et al. 1994).

A variety of ways are being explored in North America by one of us (JRA) to increase the biological control potential of P. maculiventris by judiciously using its synthetic pheromone. The system that is emerging for semiochemical manipulation of spined soldier bugs is to harvest wild adult predators in pheromone-baited traps for mass-production of their offspring to control vegetable pests. To reduce the labor involved, wild adult predators caught early in the spring are transferred directly to cages which serve as nurseries for young spined soldier bugs in vegetable fields. Synthetic pheromone lures are later placed around the perimeter of a field to disperse the army of young spined soldier bugs, and to attract the new generation of wild adult $P$. maculiventris, to suppress pest infestations.

The present investigation is part of an ongoing effort to increase the semiochemical knowledge of South and Central American predaceous pentatomids (Asopinae). This study also represents the first comparison of the chemical ecology of neotropical and nearctic asopines.

\section{Material and Methods}

Insects. $P$. nigrispinus and Supputius cincticeps (Stäl) were from laboratory colo- nies maintained at the Universidade Federal de Viçosa on house fly larvae, Musca domestica L. (Diptera: Muscidae), and larvae of a large mealworm, Zophobas confusa (Coleoptera: Tenebrionidae), respectively (Zanuncio et al. 1992). Adults of $P$. rostralis (Stäl) were collected near Goiás State, Brasil, in May 1995, and reared at the UFV on the combination of larvae under similar conditions as the above predators. Podisus sagitta (Fabricius) males used for chemical analyses were from a laboratory colony started from individuals collected near Lepaterique in south central Honduras from October to December 1993. The colony was maintained at the Escuela Agricola Panamericana, El Zamorano, Honduras in plastic Petri dishes at ambient conditions $\left(22-26{ }^{\circ} \mathrm{C}\right)$, each dish having a saturated cotton ball for humidity and water, and using fifth-instar fall armyworms \{Spodoptera frugiperda (J. E. Smith)) as prey. Podisus distinctus (Stäl) adults collected during the initial month of this study in pheromone-baited traps were transported to Beltsville, MD, where they were reared as for $P$. maculiventris (Aldrich et al. 1984), and used for chemical analyses.

Chemical Analyses. Glands were excised from $\mathrm{CO}_{2}$-anesthetized bugs submerged in tap water, and extracted in ca. $200 \mathrm{ml}$ of either hexane or $\mathrm{CH}_{2} \mathrm{Cl}_{2}$. Except for P. rostralis for which only two adult males were available, glands from 5-10 adults of each sex were excised for analysis. The metathoracic scent gland and male dorsal abdominal gland samples were analyzed separately, whereas the female dorsal abdominal gland samples were pooled for analysis. Samples from nymphs were prepared by extracting fresh exuviae which contain the contents of the previous intar's exocrine gland secretion (Aldrich et al. 1991). Samples were analyzed by gas chromatography (GC) on DB-1 ${ }^{\mathrm{TM}}$ or DB-5 $5^{\mathrm{TM}}$ columns $(0.25$ $\mu \mathrm{m}$ film, 30-m x 0.25-mm ID; J\&W Scientific, Folson, CA) in aVarian $3500 \mathrm{GC}$ with helium as carrier $(50 \mathrm{~cm} / \mathrm{sec})$, a temperature program from $50{ }^{\circ} \mathrm{C}$ for $2 \mathrm{~min}$ to $235^{\circ} \mathrm{C}$ at $15^{\circ} / \mathrm{min}$, with 
a flame ionization detector. Data were recorded using the Varian GC Star Workstation ${ }^{\mathrm{TM}}$ software. GC traces presented in figures begin at $2.5 \mathrm{~min}$ (at left) so as to exclude the solvent peak, and peaks were automatically normalized to the most abundant natural product. Electron impact-mass spectra (EI-MS) were obtained using Hewlett Packard 5971 GC-MS instruments at $70 \mathrm{eV}$ with a HP-5 ${ }^{\mathrm{TM}}$ column $(0.11 \mu \mathrm{m}$ film; $25-\mathrm{m} \times 0.2 \mathrm{~mm}$ ID), programmed from 50 ${ }^{\circ} \mathrm{C}$ for 2 min to $250{ }^{\circ} \mathrm{C}$ at $15^{\circ} / \mathrm{min}$.

Identifications based on mass spectrometry were verified by comparison and coinjection with standards. (E)-4-Oxo-2-hexenal was synthesized according to Ward and VanDorp (1969), and perilla alcohol was prepared by $\mathrm{NaBH}$ reduction of perillaldehyde (Aldrich Chemical Co., Milwaukee, WI). The other standards were obtained commercially: $(E)$-2-hexenal, $(E)$-2-hexenoic acid, $(E)$-2-octenal, $(E)$-2decenal, and $(E)$-2-decenyl acetate (Bedoukian Research Inc., Danbury, CN); trans-piperitol (PCR Research Chemicals Inc., Gainesville, FL); and the remaining standards were from Aldrich Chem.

Pheromone Field Test. Synthetic pheromones were prepared based on GC analyses of the male dorsal abdominal gland extracts of $P$. nigrispinus and $S$. cincticeps, using the percent peak areas to calculate volumes for the various components without correcting for density differences. Batches of $50 \mathrm{ml}$ of pheromone were prepared for each species using racemic mixtures for chiral compounds;

P. nigrispinus: $2.11 \mathrm{ml}($ E)-2-hexenal, $3.87 \mathrm{ml}$ benzyl alcohol, $1.30 \mathrm{ml}$ linalool, $845 \mu 1$ terpinen4-ol, $39.56 \mathrm{ml} \alpha$-terpineol, $2.08 \mathrm{ml}$ transpiperitol, and $230 \mu \mathrm{l}$ perilla alcohol; $S$. cincticeps: $21.23 \mathrm{ml}(E)$-2-hexenal, $150 \mu \mathrm{l}$ benzaldehyde, $11.04 \mathrm{ml}$ benzyl alcohol, and 23.11 $\mathrm{ml}$ linalool. Each pheromone was formulated at a $20 \%$ load (wt/wt) in plasticized polyvinyl chloride (PVC) by mixing $133.3 \mathrm{~g}$ of powdered PVC (Tenneco, Piscataway, New Jersey) with $66.7 \mathrm{ml}$ of dioctyl phthalate (Aldrich Chem.), then adding the pheromone (Fitzgerald et al.
1973). The pheromone-PVC mixture was poured into test tubes (to the top to facilitate removal from the tubes), heated at $110^{\circ} \mathrm{C}$ for $30 \mathrm{~min}$, removed from the tubes, and stored in sealed vials in a freezer until use.

Traps were made of transparent cylindrical containers with transparent lids $(20.2 \mathrm{x}$ 19.7 cm; Tri-State Molded Plastics, Inc., Dixon, $\mathrm{KY}$ ) by cutting two holes (9 $\mathrm{cm}$ diameter) in opposite sides, and covering each hole with an inwardly projecting screen funnel. The containers were turned upside-down, so that the normal top of the container became the trap bottom; small drainage holes were made in the bottom, and the bottoms were held in place by two elastic cords hooked into each screen funnel.

On September 7, 1995, 30 traps were hung (alternating treatments) from tree branches about $1.7 \mathrm{~m}$ from the ground, at least $50 \mathrm{~m}$ apart, along the hillside north of the UFV insectary building. Traps were monitored daily and rebaited every 3 days. Ten traps were baited with ca. $250 \mathrm{mg}$ slices of the P. nigrispinus pheromone in PVC, 10 traps were baited similarly with the $S$. cincticeps pheromone, and 10 traps were unbaited controls. On 18 September, 21 of the traps were moved to a new site bordering the experimental farm on the south side of the UFV campus; 9 traps were deployed around the border of experimental plots ( 3 treatment replicates), and 12 traps were deployed in a natural forest about $300 \mathrm{~m}$ northeast of the agricultural plots (4 treatment replicates).

On November 6, a new pheromone treatment was created based on results of the chemical analysis of the pheromone glands for a different Podisus sp. that was caught in traps during the initial phase of the study. The new treatment consisted of a slice of the $S$. cincticeps PVC pheromone blend and a slice of the $P$. nigrispinus $\mathrm{PVC}$ pheromone blend. This combination treatment was used in the previously unbaited control traps throughout the remainder of the study (February, 1996). 


\section{Results}

Chemical Analyses. Table 1 lists the comounds and their abundances (\%) in exocrine gland extracts of Podisus and Supputius spp. In general, the dorsal abdominal gland secretions are sex- and species-specific blends (Figs. 1, 2). The dorsal abdominal gland se-

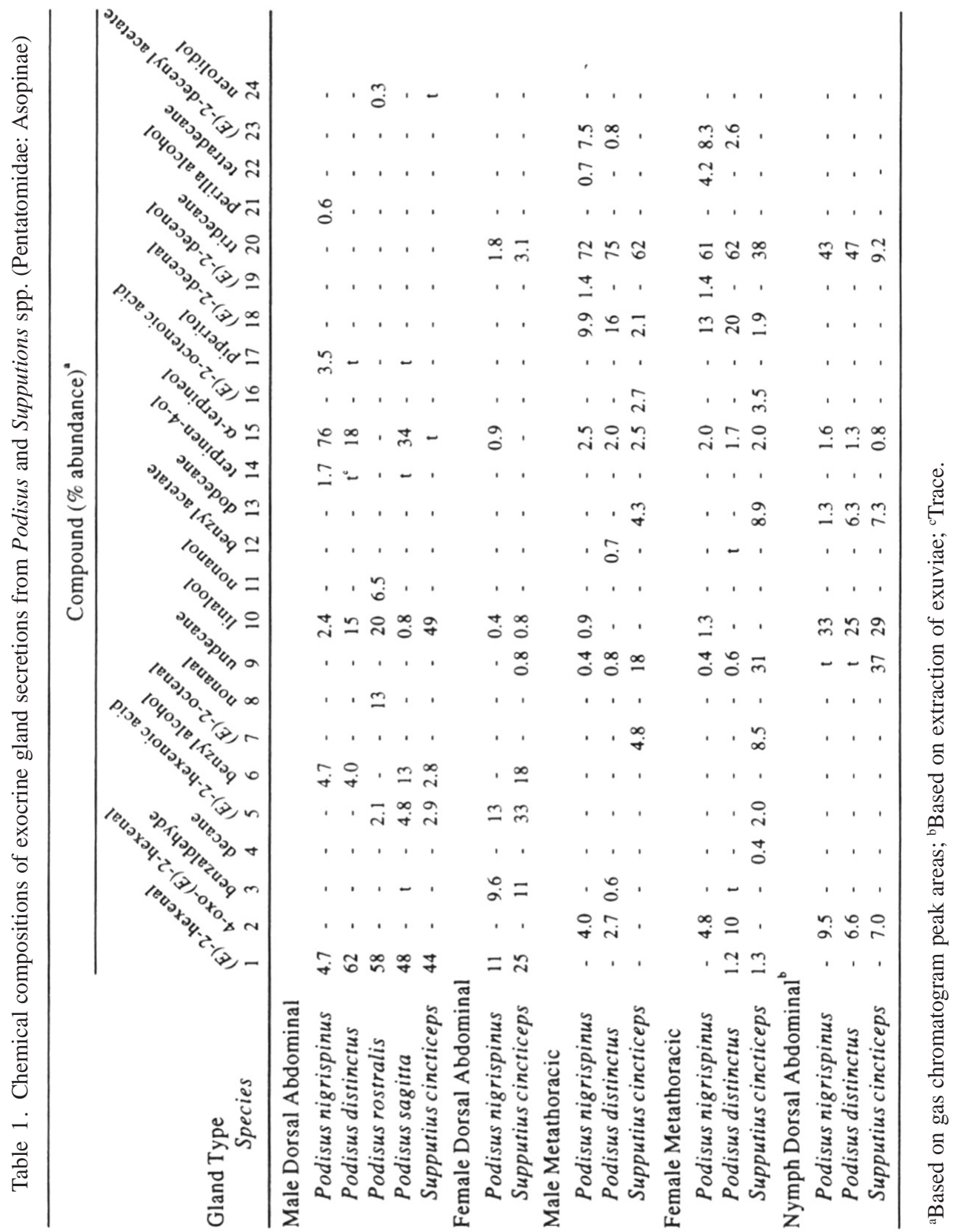


cretions of $P$. nigrispinus and $P$. distinctus nymphs are of similar composition, whereas that for $S$. cincticeps contains much more undecane (9) than tridecane (20) (Fig. 3). Dimers (probably artifacts) of (E)-4-oxo-2hexenal where detected in each exuvial extract
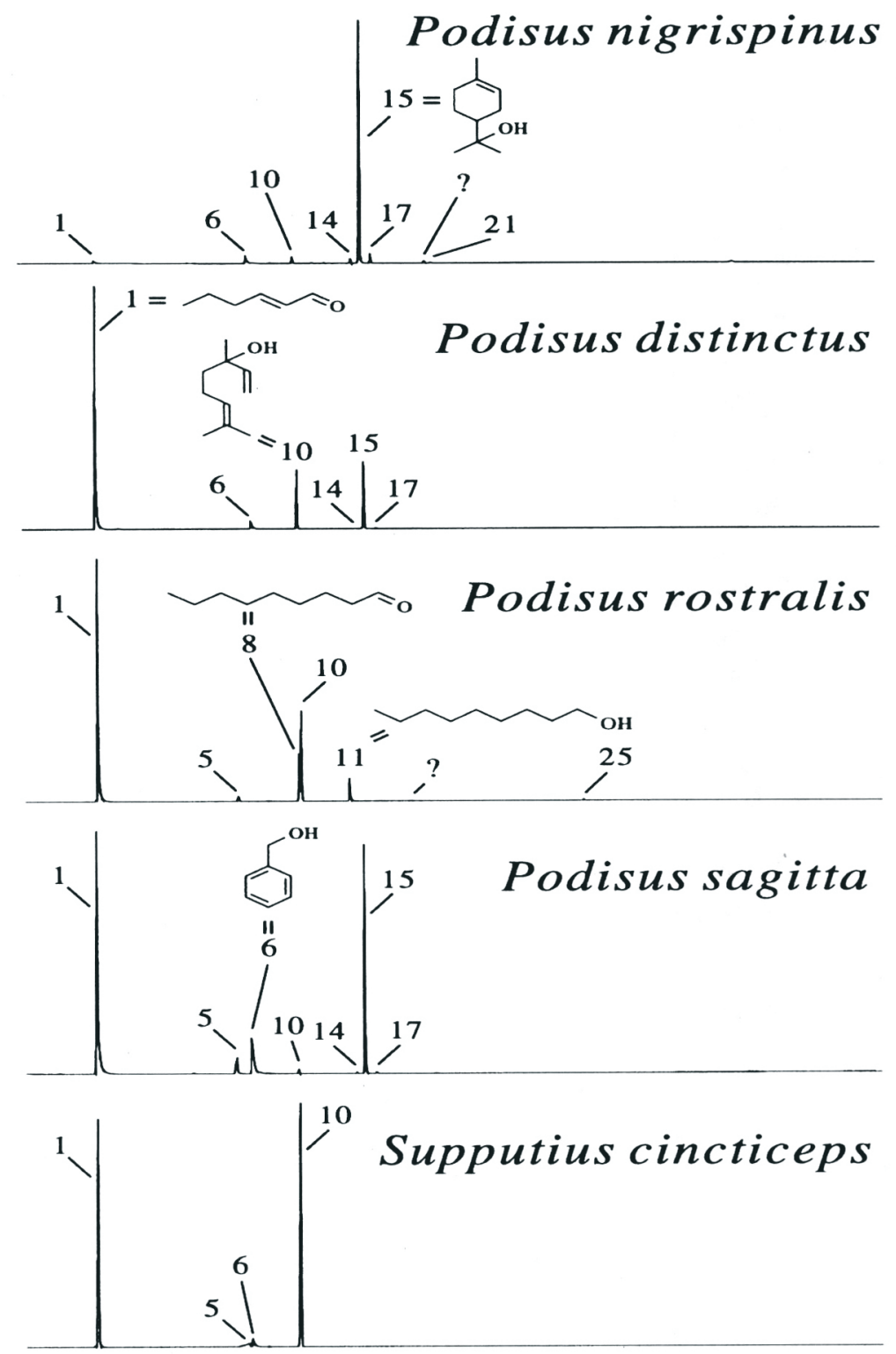

Figure 1. Gas chromatograms of extracts from the dorsal abdominal glands from the male Asopinae investigated. Numbers in the figure, and in Figures 2-4, correspond to the numbers for compounds liste in Table 1. 
Aldrich et al. 993). The metathoracic scent glands are essentially the same for males and females (Fig. 4), and are not species-specific except for very minor components (e.g. benzyl acetate(12) in P. distinctus). However, as for nymphs, the metathoracic scent gland chemistry of these species exhibits specificity at the generic level in that the secretion from $S$. cincticeps adults has relatively more undecane (9) and (E)-2-octenal (7) than is produced in the metathoracic scent glands of the Podisus spp. (Fig. 4).

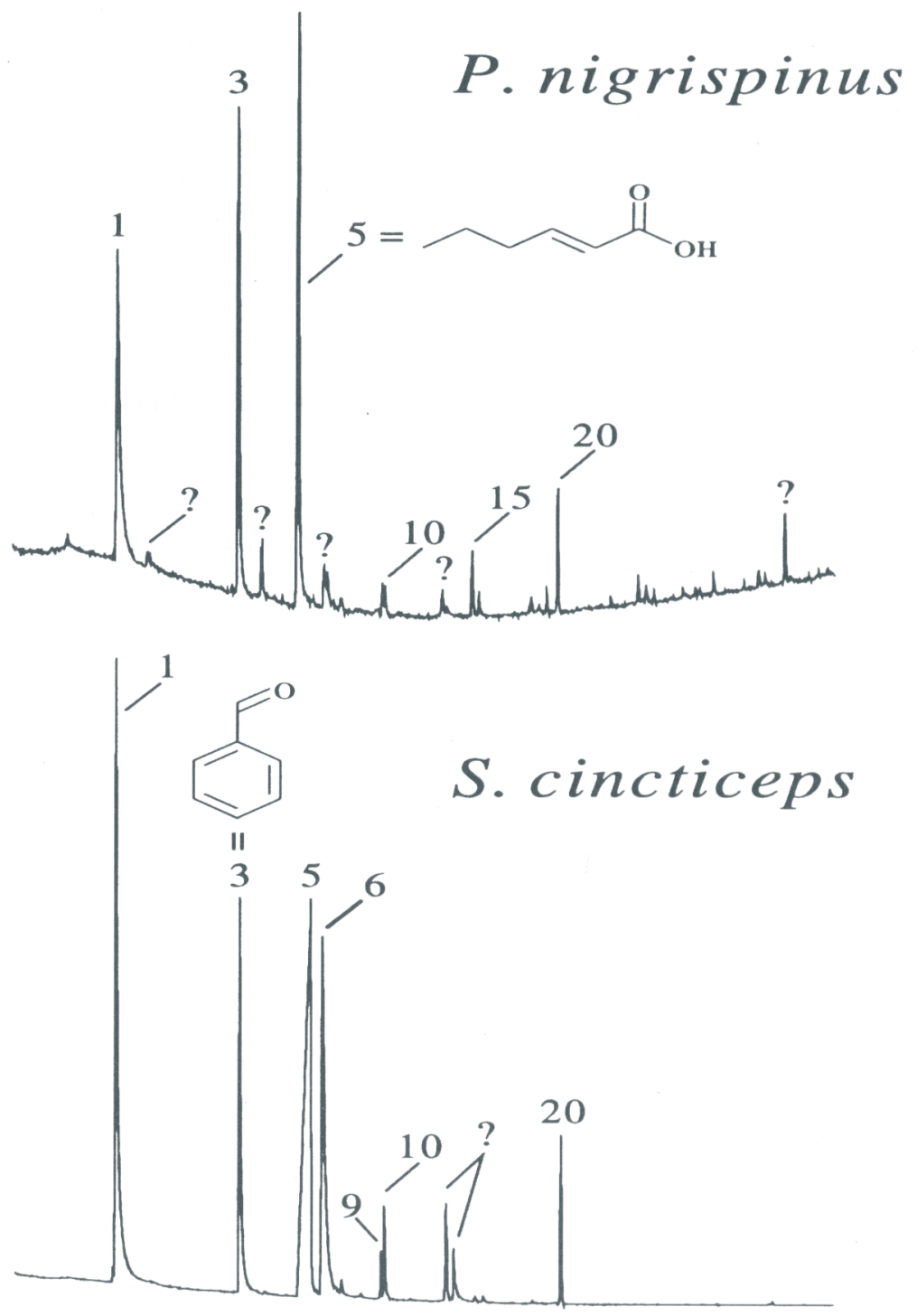

Figure 2. Gas chromatograms of extracts from the dorsal abdominal glands from females of Podisus nigrispinus and Supputius cincticeps. 
Analysis of the male dorsal abdominal gland secretion of $P$. distinctus (the unknown Podisus sp. caught at UFV; see below) was of particular interest because the results of this analysis led to a modification of the pheromone treatments being tested in Brazil. Whereas the male dorsal abdominal gland secretion of $P$. nigrispinus contained little (E)-2-hexenal or linalool, each of these compounds was a major component of the male dorsal abdominal gland secretion of $P$. distinctus (Fig. 1). Since the major components of the $S$. cincticeps synthetic pheromone were $(E)$-2-hexenal and linalool, it was decided to combine the pheromones of $P$. nigrispinus and $S$. cincticeps, and test this combination in the traps previously used as controls.

Pheromone Field Test. No individuals of $P$. nigrispinus were caught. However, 7 males and 7 females of an unknown Podisus sp. were caught in traps baited with the $P$. nigrispinus synthetic pheromone during September and October (Fig. 5), and a 2nd-instar Podisus sp. nymph was caught in a trap hung from a jambeiro tree ("rose apple", Eugenia (= Syzygium) jambos; Castro et al. 1983) behind the UFV insectary building on September 9. No Podisus sp. were attracted to traps baited with the $S$. cincticeps pheromone. The
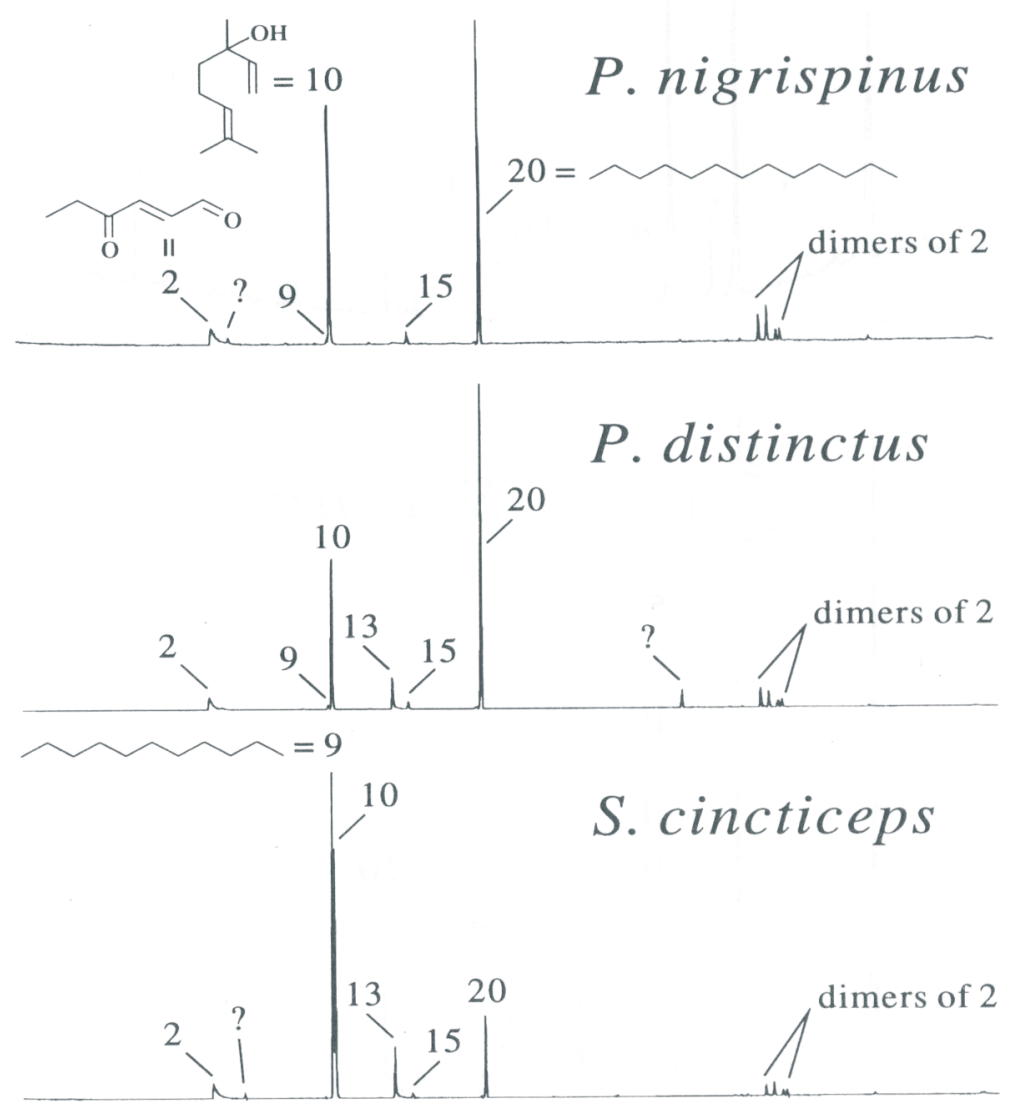

Figure 3. Gas chromatograms of exuvial extracts from laboratory-reared nymphs of Podisus nigrispinus, Podisus distinctus and Supputius cincticeps. 
adult reared from the nymph captured on 9 Spetember, and representative individuals of the unknown Podisus sp. adults caught during the 1 st two months of the study, were determined to be $P$. distinctus. After November
6, when the combined $P$. nigrispinus $/ S$. cincticeps treatment was started, $18 P$. distinctus adults were captured in the combined pheromone treatment versus $3 P$. distinctus adults in the $P$. nigrispinus pheromone

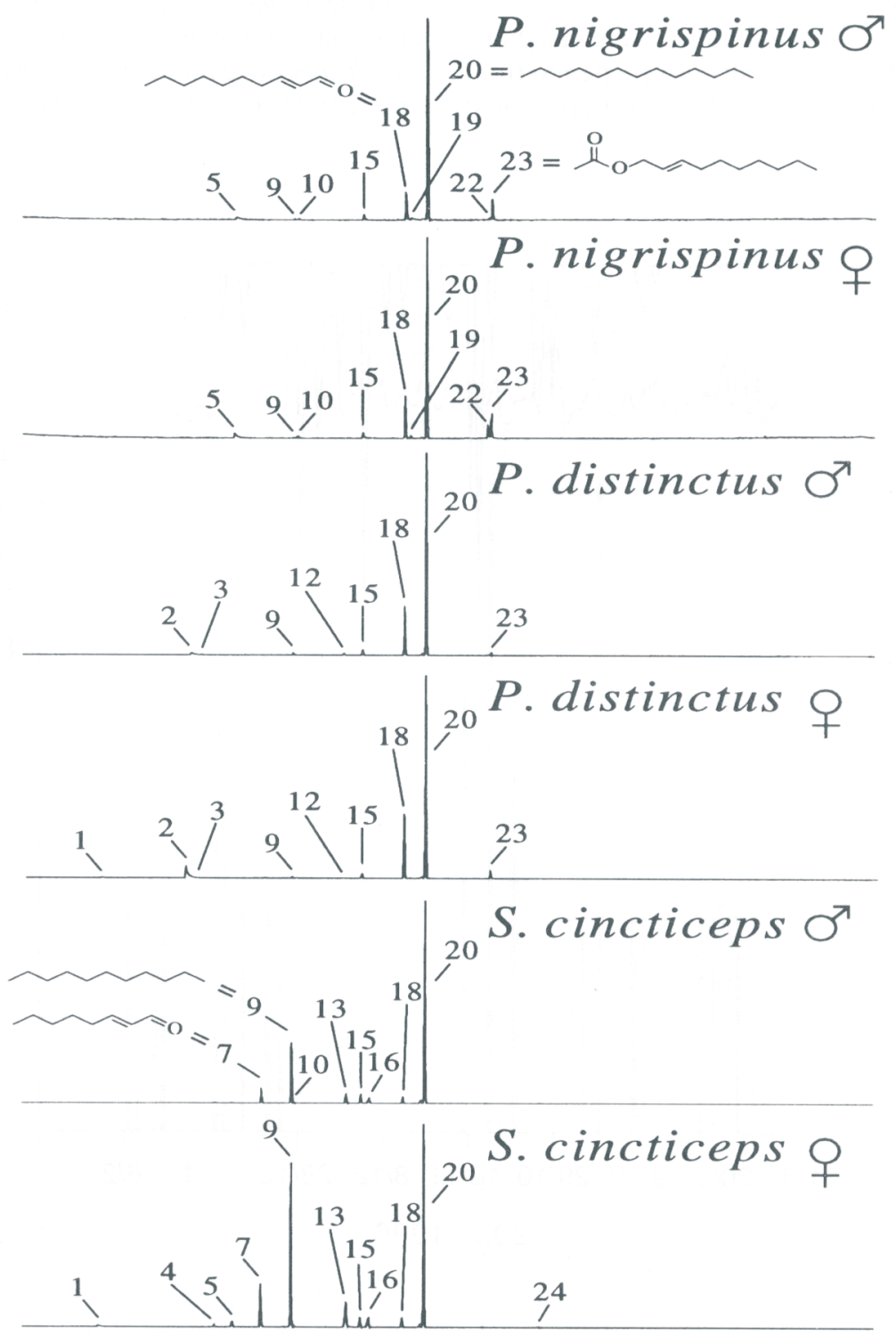

Figure 4. Gas chromatograms of extracts of the methathoracic scents glands of laboratoryreared male and female adultos of Podisus nigrispinus, Podisus distinctus and Supputius cincticeps. 
treatment $\left(\chi^{2}=10.71,1\right.$ d.f, $\left.\mathrm{P}_{0.005}=7.88\right)$. In all, 36 P. distinctus individuals were caught; 19 females, 16 males, and 1 second-instar nymph. However, no bugs were caught from November 21 through January 1, 1996, despite warm days alternating with rainy days during this period (Fig. 5).

Four S. cincticeps adults were caught (3 males and 1 female), all during a period from 17 September to 12 October in traps baited with the Supputius synthetic pheromone. Finally, 2 females of a tachinid fly, Cylindromyia atra Roeder, were caught in pheromone-baited traps; one female on 9 September in a trap baited with the $P$. nigrispinus synthetic, and the second female on 20 September in a trap baited with the $S$. cincticeps synthetic. The same species of tachinid fly was reared previously from a Podisus sp. male collected in Brasília on March 22, 1993 (J. R. Aldrich, unpublished data).

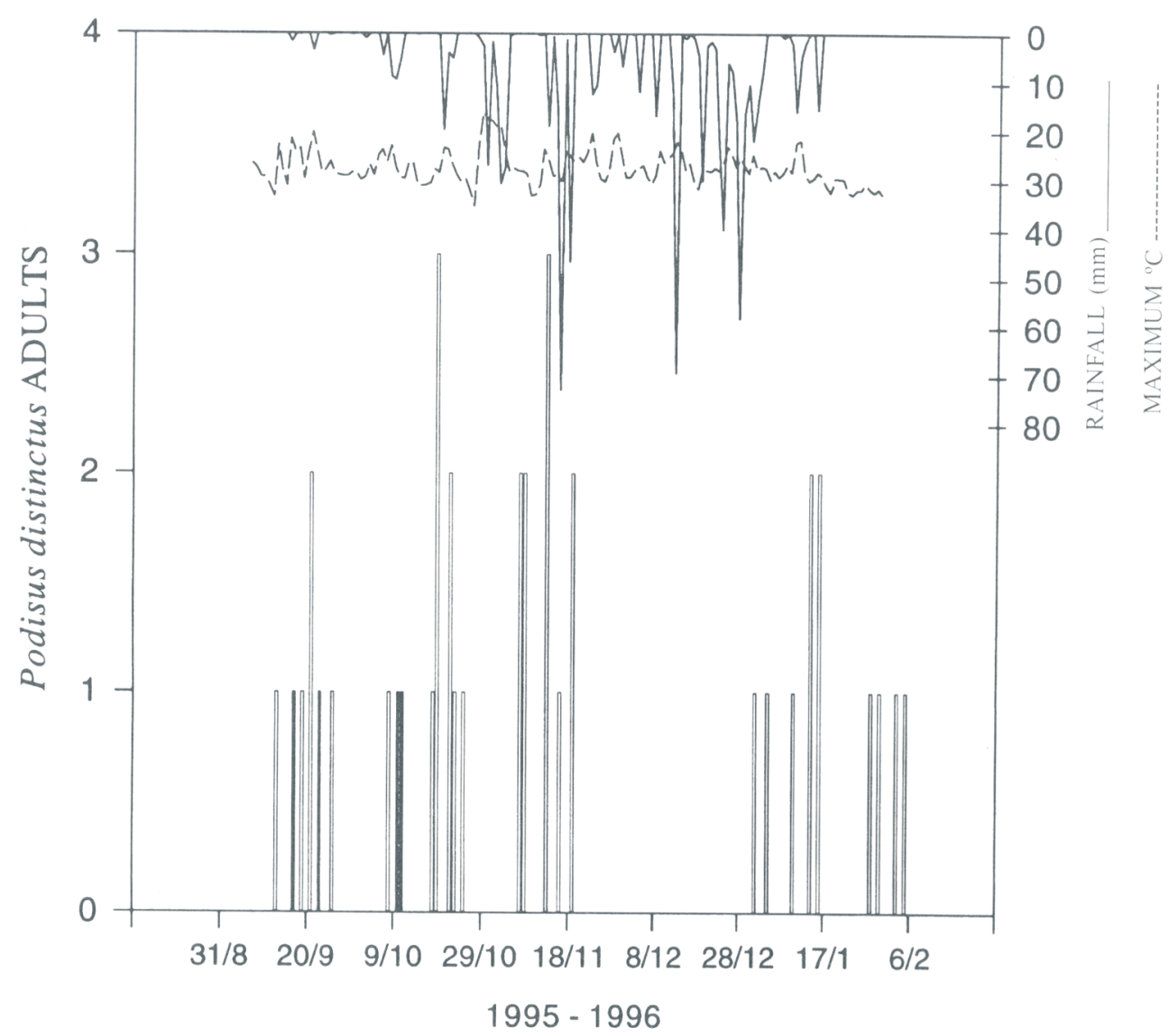

Figure 5. Adult Podisus distinctus (open bars) and Supputius cincticeps (solid bars) caught in pheromone-baited traps at the Universidade Federal de Viçosa from Spetember 7, 1995, through February 6, 1996, and associated weather data. 


\section{Discussion}

P. distinctus is the most common Podisus species in South America (Thomas 1992), and $P$. nigrispinus is the most common species in southern Brazil (Buckup 1960, Thomas 1992). Our pheromone trapping data suggest that $P$. distinctus is the more common of these two species in Minas Gerais. The abundance and distribution of $S$. cincticeps is not well known (T. Zanuncio personal communication); however the pheromone trapping data demonstrate that this species is present in Minas Gerais and relies on a pheromone to congregate.

In temperate North America, adults of the most widespread Podisus species, $P$. maculiventris, spend the winter in diapause and emerge early in the spring when they are attracted to their pheromone for a period of two to three weeks (Aldrich 1995, Aldrich et al. 1984). The main motivation for the present study was to determine if $P$. nigrispinus exhibits a peak period of pheromone responsiveness in the spring similar to that for its temperate relatives. Since seasonal changes in daylight and temperature are much less in tropical versus temperate regions, and some neotropical stink bugs are known to overwinter during the dry season under dead leaves (e.g., Panizzi \& Niva 1994), we suspected that changes in rainfall could be the primary signal stimulating emergence of aestivating $P$. nigrispinus adults (but see Denlinger 1994).

Traps baited with the synthetic pheromones for P. nigrispinus and S. cincticeps were in the field prior to the onset of the rainy season in Minas Gerais, but interpretation of the data is complicated by the fact that only $P$. distinctus adults were captured. The rain in early October appears to have stimulated an increase in the number of $P$. distinctus and $S$. cincticeps adults trapped (Fig. 5; midOctober to mid-November). Nevertheless, relatively few adults were caught compared to the situation for $P$. maculiventris in North America where 50 or more adults/trap/day are sometimes caught at the peak of the emergence (Aldrich 1995). However, six times more
$P$ distinctus adults were caught in traps baited with the combination of $P$. nigrispinus and $S$. cincticeps pheromones than in traps baited only with the $P$. nigrispinus pheromone. Therefore, if the combination pheromone had been used from the beginning of the study, perhaps 90 or more $P$. distinctus adults would have been captured instead of just the 15 individuals that were trapped using the $P$. $n i$ grispinus blend. Moreover, a new type of trap recently developed for monitoring phytophagous pentatomid bugs (Mizell \& Tedders 1995) appears to be much more effective in harvesting predaceous pentatomids than the type of trap used in the present study (J. R. Aldrich, unpublished data).

Pheromone trapping data for P. maculiventris in the U.S. also show that for about six weeks after the spring emergence very few adult predators are caught, and then the new generation of adults starts to be attracted. There was a comparable gap in attraction of $P$. distinctus adults from mid-November through January, followed by a resumption of attraction. Furthermore, the discovery that at least one neotropical tachinid fly uses asopine pheromones as host-finding kairomones is similar to the semiochemistry of $P$. maculiventris and other temperate predaceous bugs where a variety of parasitoids exploit pheromones to find these hosts (Aldrich 1995). Thus, the phenology of the neotropical asopines is essentially like that for P. maculiventris in temperate North America (Aldrich 1995), but less striking in terms of the numbers of predators and host-seeking parasitoids attracted.

Assessment of whether or not neotropical asopines are as abundant as their temperate counterparts requires further study. Our identifications of candidate pheromones for two other neotropical asopines, $P$ sagitta and $P$. rostralis, provide additional opportunities to test of this concept. More extensive research is needed, for example, to determine where and when P. nigrispinus occurs, or if the pheromone tested thus far for this species is somehow flawed. In any case, our results indicate 
that neotropical asopines rely on pheromones composed of simple, commercially available compounds to find one another. One challenge now is to devise ways to use pheromones of these predators to maximize their biological control effectiveness in tropical agricultural systems.

\section{Acknowledgments}

We thank Mr. Tev Barros for technical assistance, and Mr. Josué Sant'Ana, Universidade Federal do Rio Grande do Sul, Departamento de Fitossanidade, Porto Alegre, RS, Brazil, for help preparing the resumo and reviewing the manuscript. Dr. Norman E. Woodiey (USDA Systematic Entomology Laboratory, Beltsville) and Dr. Donald B. Thomas (USDA Subtropical Agriculture Research Laboratory, Weslaco, Texas) determined the tachinid and pentatomid species, respectively, for which we are grateful. We also thank the USDA Organization for International Cooperative Development for financially supporting the project.

\section{Literature Cited}

Aldrich, J. R. 1995. Chemical communication in true bugs and exploitation by parasitoids and commensals, p. 318-363. In R. T. Carde \& W. J. Bell (eds.), Chemical Ecology of Insects II. Chapman \& Hall, New York, 433p.

Aldrich, J. R., J. P. Kochansky, W. R. Lusby \& M. Borges. 1991. Pheromone blends of predaceous bugs (Heteroptera: Pentatomidae: Podisus spp.). Z. Natur-forsch. 46C: 264-269.

Aldrich, J. R., J. P. Kochansky \& C. B. Abrams. 1984. Attractant for a beneficial insect and its parasitoids: Pheromone of the predatory spined soldier bug,
Podisus maculiventris (Hemiptera: Pentatomidae). Environ. Entomol. 13: 10311036.

Aldrich, J. R., H. Numata, M. Borges, F. Bin, G. K. Waite \& W. R. Lusby. 1993. Artifacts and pheromone blends from $\mathrm{Ne}$ zara spp. and other stink bugs (Heteroptera:Pentatomidae).Z. Naturforsch. 48C:73-79.

Anonymous. 1992. Wanted: a few good soldier (bugs). Science 257: 1049.

Berti Filho, E. \& A. I. A. Fraga. 1987. Inimigos naturais para o controle de lepidópteros desfolhadores de Eucalyptus sp. Brasil Florestal 62: 18-22.

Biever, K. D. \& R. L. Chauvin. 1992a. Timing of infestation by the Colorado potato beetle (Coleoptera: Chrysomelidae) on the suppressive effect of field released stinkbugs (Hemiptera: Pentatomidae in Washington. Environ. Entomol. 21:12121219.

Biever, K. D. \& R. L. Chauvin, R. L. 1992b. Suppression of the Colorado potato beetle (Coleoptera: Chrysomelidae) with augmentative releases of predaceous stinkbugs (Hemiptera: Pentatomidae). J. Econ. Entomol. 85: 720-726.

Buckup, L. 1960. Pentatomideos Neotropicais-II. Contribuição ao conhecimento do Asopinae da América do Sul (Hem. Het. Pentatomidae). lheringia 15: 1-25.

Castro, H. A. de, T. L. Krügner, C. H. F. Ideriha, |M. S. C. Cappello \& A. B. Marchi. 1983. Inoculação cruzada de Eucalyptus, goiaba (Psidium guajava) e jambeiro (Syzygium jambos) com Puccinia psidii. Fitopatol. Bras. 8: 491-497. 
Denlinger, D. L. 1994. The beetle tree. Amer. Entomol.40: 168-171.

Fitzgerald, T. D., A. D. St. Clair, G. E. Daterman \& R. G. Smith. 1973. Slow release plastic formulation of the cabbage looper pheromone cis-7-dodecenyl acetate: Release rate and biological activity. Environ. Entomol. 2:607-610.

Hough-Goldstein, J. \&C. B. Keil. 1991. Prospects for integrated control of the Colorado potato beetle (Coleoptera: Chrysomelidae) using Perilius bioculatus (Hemiptera: Pentatomidae) and various pesticides. J. Econ. Entomol. 84: 1645-1651.

Hough-Goldstein, J. \& J. Whalen. 1993. Inundative release of predatory stink bugs for control of Colorado potato beetle. Biol. Control 3:343-347.

Hunter, C. D. 1994. Suppliers of beneficial organisms in North America. California Environmental Protection Agency, Sacramento, $30 \mathrm{p}$.

Legaspi, J. C. \& R. J. O’Neil. 1993. Life history of Podisus maculiventris given low numbers of Epilachna varivestis as prey. Environ. Entomol. 22: 1192-1200.

Legaspi, J. C. \& R. J. O’Neil. 1994. Developmental response of nymphs of Podisus maculiventris (Heteroptera: Pentatomidae) reared under low numbers of prey. Environ. Entomol. 23: 1254-1259.

Mizell, R. F. \&W. L. Tedders. 1995. Use of the Tedders trap to monitor stink bugs in 11. Proc. Southeast Pecan Growers Assoc. 88: 36-40.

O'Neil, R. J. 1990. Functional response of arthropod predators and its role in the biological control of insect pests in agricultural systems. In R. R. Baker \& P. E. Dunn (eds.), New directions in biological control: alternatives for suppressing agricultural pests and diseases. UCLA Symp. Mole. Cell Biol. 112: 83-96.

O’Neil, R. J. \& R. N. Wiedenmann. 1987. Adaptations of arthropod predators to agricultural systems. Fla. Entomol. 70: 41-48.

Panizzi, A. R. \& C. C. Niva. 1994. Overwintering strategy of the brown stink bug in northem Paraná. Pesq. Agropec. Bras. 29: 509-511.

Pfannenstiel, R. S., R. E. Hunt \& K. V. Yeargan. 1995. Orientation of a hemipteran predator to vibrations produced by feeding caterpillars. J. Ins. Behav. 8: 1-10.

Thomas, D. B. 1992. Taxonomic Synopsis of the Asopine Pentatomidae (Heteroptera) ofthe Western Hemisphere. The Thomas Say Foundation, Volume XVI, Entomol. Soc. Am., Lanham, Maryland, 156 p.

Turnipseed, S. \& M. Kogan. 1983. Soybean pests and indigenous natural enemies. In H. N. Pitre (ed.), Natural enemies of arthropod pests in soybean. Southern Cooperative Series Bull. 285, South Carolina Agrult. Exp. Stn., 90 p.

Valicente, F. H. \& R. J. O'Neil. 1995. Effects of host plants and feeding regimes on selected life history characteristics of $\mathrm{Po}$ disus maculiventris (Say) (Heteroptera: Pentatomidae). Biol. Control 5: 449-461.

Ward, J. P. \& D. A. VanDorp. 1969. A stereospecific synthesis of 4-oxo-2 transhexenal. Recueil 88:989-993. 
Wiedenmann, R. N. \& R. J. O'Neil. 1992. Searching strategy of the predator $\mathrm{Po}$ disus maculiventris (Say) (Heteroptera: Pentatomidae). Environ. Entomol. 21:1-9.

Zanuncio, J. C., J. B. C. Alves, R. C. Sartório \& J. E. M. Leite. 1992. Métodos para criação de hemipteros predadores de lagartas. An. Soc. Entomol. Brasil 21: 245-251.

Zanuncio, J. C., J. B. C. Alves, T. V. Zanuncio \& J. F. Garcia. 1994. Hemipterous predators of eucalypt defoliator caterpillars. Forest Ecol. Manage. 65: 53-63.

Received 30/V/96. Accepted 3/XII/96. 